\title{
Assessment of thromboembolic disease in the context of evidence-based nursing
}

\section{L'. Tkáčová1, B. Grešš Halász', M. Murgová2, M. Gliganičová2}

\section{Original Articles}

${ }^{1}$ St. Elizabeth University of Health and Social Work in Bratislava, Slovak Republic

${ }^{2}$ Department of Blessed P. P. Gojdič and Blessed Dominic Trčka Michalovce, Slovak Republic

\section{Correspondence to:}

St. Elizabeth University of Health and Social Work, Department of Blessed P. P. Gojdič and Blessed Dominic Trčka Michalovce, Nám. slobody 3, P. O. Box 104, 810 00, Bratislava, Slovak Republic

Submitted: 23.4.2016

Revised: 1.6.2016

Accepted: 15.8.2016

\section{Reviewers:}

Pawel S. Czarnecki

Rector of the Warsaw Management University, Poland

A. Wolf

Association of palliative and hospice care, Kiev, Ukraine

\section{Key words:}

Deep vein thrombosis, pulmonary embolism, practice based on evidence, thromboembolism

CSWHI 2016; 7(2): 91-96 (c) 2016 Clinical Social Work and Health Intervention

\section{Abstract:}

The aim of the study was to find out how nursing behavior is perceived by nurses and patients with thromboembolic disease. The sample consisted of 264 patients, and a comparative sample consisted of 92 nurses. The standardized measuring tool Caring Behaviors Inventory (CBI-24) was used for the data collection, supplemented by questions of its own design. Exploratory methods and chi-square test of independence were used for the needs of statistical processing. Based on the results it can be concluded that the perception and assessment of the provided nursing care was more positively evaluated by the patients.

\section{Introduction}

We encounter the issue of thromboembolic disease in virtually all fields of medicine. It is a condition characterized by a blood clot - thrombus in a certain place of blood circulation, but especially in the deep veins of the legs and its subsequent pulmonary embolism. It directly threatens the patient's life, reduces its quality, prolongs 
hospitalization, aggravates postoperative course, which of course increases the cost of a medical facility. According to the European Statistical Institute, TED is the second most common medical complication, the second leading cause of prolonged patient hospitalization and the third leading cause of death (Eurostat Statistics Explained, 2015). The most important prevention of TED in nursing care is the early mobilization of the patient, the proper bandaging of legs, patient positioning and adequate hydration. A nurse should seek the care management and coordination of the various procedures, to reduce the risk of dehydration to a minimum (Kabátová, Puteková 2015). A risk factor is not only posed by operating performance, but also older age, obesity, fractures of the lower limbs and malignancy. The problem in the prevention of thromboembolic disease is the lack of information on preventive measures or risk factors (Widimský, Malý et al., 2005). Nursing access to evidence-based practice is different from the standard biomedical model. The nurse provides holistic care, but rather works with the patient than on them. Within decision-making, the nurse must consider not only the effectiveness of treatment, but also the choice of interventions, acceptability by the patient and also cost effectiveness. Therefore, evidence-based nursing practice is a process in which the best practices are associated with nurse expertise and the patient's preferences, ensuring optimal care (Jarošová, Zeleniková, 2014).

\section{Patients and Methods}

The aim of this study was to identify problem areas in meeting the needs of patients with TED, finding out how patients with TED perceive the provided nursing care and how nurses perceive the nursing care of patients with TED. The sample consisted of 264 patients, and a comparative sample consisted of 92 nurses. Respondents were chosen through purposive sampling. The research was conducted from October 2015 to January 2016. The selected research method was quantitative research. The use of tools for data collection was standardized questionnaire, supplemented by questions on its own design. The standardized measuring tool Caring Behaviors Inventory (CBI-24) was used for the data collection. CBI is based on Watson's transpersonal theory of care. CBI-24 items are grouped into four dimensions of nursing care:

1st dimension - security, includes 8 items, security in dealing and patient care; coming into the patient's room of their own will; communicating with patients; prompting the patient to voice their problems; helping with pain management; expressions of interest in the patient; timely implementation of therapeutic procedures and drug administration; the management of symptoms of the disease;

2nd dimension - knowledge and skills, includes 5 items, skill when administering injections; professional knowledge and skills; intelligent use and handling of equipment and devices; confidential treatment of the patient; responding quickly to the patient's call;

3rd dimension - respect, includes 5 items, attentive listening to the patient; individual approach to the patient; encouraging the patient; manifestation of empathy and identification with the patient; enabling patient to express their feelings about the illness and treatment; performance of expressed and unexpressed needs of the patient;

4th dimension - connectedness, includes 6 items, providing information and patient education; spending time with the patient; assisting the patient in their development; manifestation of patience and perseverance in patient care; involving the patient in their care planning (Wu, Larrabee, Putman, 2006). From among the statistical methods, 
the chi-square test was used. $\mathrm{P}<0.05 \%$ is the $\%$ difference of patients versus nurses; it is statistically significant at the $5 \%$ significance level. $\mathrm{P}>=0.05$, the difference is not statistical. The multinomic division homogeneity test was used to test the hypotheses. Classic test of independence or homogeneity is based on the test of good conformity, thus comparing the expected frequencies in each cell in the table (assuming that the observed values of both characters are independent of each other) and actual frequencies. Categorical variables were assessed using the $\chi 2$ test. Statistical tests were evaluated at the statistical significance level $\alpha=$ 0.05 (Pavlíček, Dobríková, 2007).

\section{Results and Discussion}

The assumption that within nursing care, patients with TED better evaluate nursing interventions as meeting their needs was verified by the $\mathrm{t}$ - test statistical method. The result is shown in Table 1. Patients whose evaluation was generally higher included nursing skills regarding the administration of injections, professional knowledge and skills, alleviation of the disease symptoms in a patient, help with pain management in the patient and timely implementation of therapeutic procedures and administration
Table 1 Comparison of nursing interventions and the patient's needs

\begin{tabular}{|l|c|l|}
\hline & $\begin{array}{l}\text { Nursing } \\
\text { interventions }\end{array}$ & $\begin{array}{l}\text { Patient's } \\
\text { needs }\end{array}$ \\
\cline { 1 - 2 } $\begin{array}{l}\text { Average } \\
\text { evaluation }\end{array}$ & 1.25 & 1.36 \\
\cline { 1 - 2 } $\mathrm{T}-$ test & \multicolumn{2}{|c|}{$\mathrm{P}=0.001$} \\
\cline { 1 - 2 } difference & \multicolumn{2}{|c|}{0.11} \\
\hline
\end{tabular}

Source: Our own research

of drugs as the most important items. The listed items are part of the Security dimension and Skills and Experience dimension. We accept the assumption.

Next, we compared the perception of nursing care in relation to the intervention procedures from the perspective of patients and nurses, following the CBI - 24 standardized questionnaire. Based on an overall evaluation of the provided nursing care from the perspective of both studied groups, the $\mathrm{t}$ - test did not discover any statistically significant difference $\mathrm{p}=0.14$ in the perception of the monitored areas. The result is shown in Table 2.

When evaluating the various dimensions of the questionnaire, i.e. respect,

Table 2. Evaluation of nursing care in relation to the intervention procedures by both groups comparison

\begin{tabular}{|l|c|c|c|c|}
\hline \multicolumn{1}{|c|}{$\begin{array}{c}\text { Dimension of CBI } \\
\text { questionnaire }\end{array}$} & patients & nurses & $\mathrm{t}$ - test & $\mathrm{p}$ - value \\
\hline CBI & $4.61(0.75)$ & $5.03(0.44)$ & 6.31 & 0.0000 \\
\hline respect & $4.39(0.88)$ & $4.90(0.56)$ & 6.53 & 0.0000 \\
\hline connectedness & $4.31(0.90)$ & $4.67(0.54)$ & 4.83 & 0.0000 \\
\hline $\begin{array}{l}\text { knowledge and } \\
\text { experience }\end{array}$ & $5.06(0.76)$ & $5.27(0.63)$ & 3.10 & 0.0020 \\
\hline security & $4.69(0.81)$ & $5.21(0.56)$ & 7.07 & 0.0000 \\
\hline
\end{tabular}

Source: Our own research 
connectedness, security, knowledge and experience, we found that the results of the questionnaire are not very different for the patients and nurses, despite the more positive perception of the patients who considered the nursing activities in a more positive manner. Statistical difference between patients and nurses is found in the dimension of knowledge and experience $\mathrm{p}=0.030$ and the dimension of connectedness $p=0.002$; in other areas we did not find a statistical difference. Based on the above, the assumption cannot be accepted.

We also assumed that the nurses attending to patients with TED are more concerned with the pragmatic than the humanistic area. The terms "care" and "nursing care" represent the activities and values of nursing. Nursing is the moral and ethical basis of caregiving and its essence. Although it is difficult to clearly define nursing - care in caregiving, experts agree that it should include two basic components - instrumental and expressive. The instrumental component refers to the physical and technical aspects of care, while the expressive element is associated with the implementation of the psychosocial and emotional needs of the patient. Based on these findings, we focused on comparing the technical focus of nurses and the humanistic approach. When evaluating we used the dimension of knowledge and experience that we assigned to the pragmatic area and the dimension of respect, which is the humanistic area. Based on statistical processing using $\mathrm{t}$ - test $(\mathrm{p}=0.025)$, we found that the pragmatic area, meaning experience and knowledge, is better evaluated by nurses than the area of the humanistic approach to the patient. The result is shown in Table 3. We accept the assumption.

We assumed that nurses are more focused on performance than on establishing a relationship of security and safety for patients. In the evaluation we used the comparison results of the Knowledge and Experience
Table 3. Evaluation of nurses in humanistic and pragmatic field of nursing care

\begin{tabular}{|l|c|c|}
\hline & $\begin{array}{l}\text { pragmatic } \\
\text { focus }\end{array}$ & $\begin{array}{l}\text { humanistic } \\
\text { approach }\end{array}$ \\
\cline { 1 - 2 } $\begin{array}{l}\text { Average } \\
\text { evaluation }\end{array}$ & 5.4 & 4.8 \\
\cline { 1 - 2 } $\mathrm{T}-$ test & \multicolumn{2}{|c|}{$\mathrm{P}=0.024$} \\
\cline { 1 - 2 } difference & \multicolumn{2}{|c|}{0.6} \\
\hline
\end{tabular}

Source: Our own research

dimension and Security dimension. From the perspective of nurses, items focused on performance were more positively rated than items with a focus on security. From the statistical compilation based on the $t$ test $(p=0.036)$ it is possible to accept the assumption.

Table 4. Evaluation of nurses focused on performance and establishing a relationship of security in nursing

\begin{tabular}{|l|c|c|}
\hline & $\begin{array}{l}\text { focus of nurses } \\
\text { on performance }\end{array}$ & $\begin{array}{l}\text { providing } \\
\text { security to } \\
\text { the patient }\end{array}$ \\
\hline $\begin{array}{l}\text { Average } \\
\text { evaluation }\end{array}$ & 5.4 & 5.2 \\
\cline { 1 - 1 } T-test & \multicolumn{2}{|c|}{$\mathrm{p}=0.034$} \\
\cline { 1 - 1 } difference & \multicolumn{2}{|c|}{0.2} \\
\hline
\end{tabular}

Source: Our own research

The first surveyed area in our research was respect, in which the results of the responses of patients and nurses indicate almost identical perceptions of the two compared groups. We agree with Baňovičová and Bubeníková (2011), who state that the ability to empathize with others is an important prerequisite for the job as a nurse and at the same time empathy can be seen as a kind of communication. The second area surveyed in the questionnaire was the 
Connectedness dimension - it means to be available to the patient and help them to actively participate in their care, and has emerged from the expert discussion of nursing professionals and professional English teachers. Berman, Snyder et al. (2012) state, inter alia, that the Connectedness dimension means ensuring a supportive, protective and positive environment for the patient. In this area, we noticed slight differences in perception on the part of patients and nurses. The third surveyed area of our research was the skills and experiences of nurses in nursing care. On closer examination of the results of our research it can be assumed that it is mainly influenced by the length of experience, age and education of individual nurses. However, the issue of motivation and interest come to the fore in connection with the above mentioned facts, in addition to adequate education and skills (Kabat, 2015). The last surveyed questionnaire area was the area of security. Here we recorded similar perception on the part of both patients and nurses based on the results of the questionnaire responses; a statistically significant difference $(p=0.046)$ was also seen in a negative response to the question of communication with the patient. This area was more positively assessed by nurses than patients. Communication is a crucial but often underestimated element in providing quality nursing care for older people. It is the basis of the relationship between nurse and patient. It is particularly important for elderly patients because of their ability to understand and stick to their treatment and their satisfaction with nursing care providers are largely influenced just by communication (Kabátová, 2015). Pokorná (2008) states in her research investigations that nurses rate their overall communication skills better than patients. From this it can be inferred that communication is among the weaker skills of nurses in nursing care.

\section{Conclusion}

The study found that there are differences in the perception of nursing behavior between nurses and patients. Comparison of the views of patients and nurses is important as feedback for caregivers and for the development of nursing care focused on the patient. The patients' perception of care is important information for nursing practice and research, because the main recipient of nursing care is the patient. One of the main assumptions of this model is the patients' perception of quality of care. The results of the research show that technical skill is better evaluated by nurses than humanistic approach to the patient. Conversely, patients evaluated the nursing fields focused on performance better than the creation of a sense of safety and security for the patient. The area of communication appeared problematic. The ability of communication between the patient and the nurse is affected by disease progression. The nurse must always keep in mind that even if the patient is unable to communicate verbally, they still perceive and experience emotions (Martinková, 2016). It should also be noted that patients generally evaluated nursing behavior in caregiving better and more positively than nurses.

\section{References}

1. BÁNOVIČOVÁ, L.- BUBENÍKOVÁ, M. 2011. Empathy in Nursing. In Nursing and Midwifery. [online]. 2011, vol. 2, issue 1, p. 165 -170. [cit. 2016-02-28]. Available on the Internet:http://periodika.osu.cz/osetrovatelstviaporodniasistence/dok/201101/4 banovcicova_bubenikova.pdfn. ISSN 1804-2740.

2. BERMAN, A.- SNYDER, S. et al. 2012. Kozier \& Erb's Fundamentals of Nursing: Concepts, Process, and Practise. 9th ed. New Jersey (USA): Pearson International 
Edition. 2012. 1631 p. ISBN: 978-0-13261137-4.

3. EUROSTAT STATISTICS EXPLAINED. 2015. Statistics of Causes of Death. [online]. 2015 [cit. 2015-09-28]. Available on the Internet: http://ec.europa.eu/eurostat/ statistics-explained/index.php/Causes_of_ death_statistics/sk.

4. JAROŠOVÁ, D.- ZELENÍKOVÁ, R. 2014. Evidence Based Nursing. Grada Publishing, a.p. Prague, 2014. p. 136 ISBN 978-80247-5345-4.

5. KABÁTOVÁ, O. 2015. Expressions of Elderspeak in Nursing Practice. In New Trends in Nursing II. Trnava : Trnava University in Trnava, Faculty of Health and Social Work, 2015. p. 76 - 82. ISBN 978-80-8082-864-6.

6. KABÁTOVÁ, O. 2015. Interest of Nursing Students in Working with Seniors. In Nursing and Midwifery. - ISSN 1336-183X. - issue 6 (2015), p. 53-55.

7. KABÁTOVÁ, O.- PUTEKOVÁ, S. 2015. Nursing Care in Geriatrics II. 1. pub. - Trnava: Typi Universitatis Tyrnaviensis, 2015. - p. 84 ISBN 978-80-8082-918-6.
8. MARTINKOVÁ, J. 2016. Management of Problem Behavior in Patients with Dementia in a Medical Facility. In Deinstitutionalisation of Social Services in the Context of Helping Professions. Bratislava: St. Elizabeth University of Health and Social Work, DP Michalovce, 2016. p. 230 - 237. ISBN $978-80-8132-144-3$.

9. PAVLÍČEK, J.- DOBRÍKOVÁ, P. 2007. Social Research and Statistical Data Processing. Bratislava: St. Elizabeth University of Health and Social Work, 2007. p. 81 ISBN 978-80-89271-16-0.

10. POKORNÁ, A. 2008. Effective Communication Techniques in Nursing. 2. pub. Brno: NCO NZO, 2008. p. 100 ISBN 978-807013-466-5.

11. WIDIMSKÝ, J.- MALÝ, J. et al. 2005. Acute Pulmonary Embolism and Venous Thrombosis. 2. pub. Prague: Triton, 2005. p. 384 ISBN 80-7254-639-2.

12. WU, Y.- LARRABEE, J. H.- PUTMAN, H. P. 2006. Caring Behaviors Inventory. A reducing of the 42-Item Instrument. In Nursing Research, vol. 55, issue 1, p. 13-25. 